TEME, г. ХLIII, бр. 3, јул - септембар 2019, стр. 927-929

Приказ дела

Примљено: 8. 12. 2017.

Одобрено за штампу: 20. 10. 2019.

\title{
ДОПРИНОС ИЗГРАДЫИ МИРА СВЕШТЕНИЦА ИЗ ПРОТЕСТАНТСКИХ ЦРКАВА У ВОЈВОДИНИ *
}

\author{
Ненад Кнежевић \\ Универзитет у Београду, Факултет политичких наука, Београд, Србија \\ nenad.knezevic@aol.com
}

Рукоположење жена у свештенички чин већ је у 19. веку, током првог таласа феминизма, постављено као озбиљна тема и изазов за традиционалне хришћанске верске заједнице. Од првих захтева за изједначавање мушкараца и жена унутар црквене хијерархије протекло је неколико деценија док женама постепено није омогућено да постану свештена лица у појединим протестантским црквама током прве половине 20. века. Историја те борбе, која у многим хришћанским заједницама траје и данас, обележена је теолошким расправама и жестоким унутарцрквеним сукобима, укључујући и примере раскола изазваних уласком жена у црквену хијерархију.

Иако се то не би могло закључити на основу самог наслова, књига Допринос изградњи мира жена свештеница из протестантских иркава у Војводини највећим се делом бави управо историјом женског свештенства на подручју Србије (конкретније, Војводине). Кроз ову сажету књигу, која обухвата свега стотинак страница, проф. Свенка Савић, ауторка, прати деловање жена свештеница унутар три протестантске заједнице које су биле предмет њеног истраживања: Словачке евангеличке цркве, Реформатске хришћанске цркве и Евангеличке методистичке цркве. Иако нису све три цркве званично класификоване као традиционалне од стране државе, ауторка их оправдано сматра таквима с обзиром на дуг континуитет њиховог постојања на подручју Војводине (стр. 13).

Након кратких уводних напомена везаних за теолошке и обредне посебности ових цркава, ауторка је приступила представљању биографских података жена које су до сада служиле или још увек служе у овим заједницама као свештенице. Откривају нам се имена жена различитог порекла и различитих животних прича које су до сада биле неиспричане, а са њима и један свет верских искустава и пракси ових мањинских верских заједница, о којима већинско становништво у Србији зна веома мало или нимало. Подаци су најпре изложени наративно, попут одредница у популарним „Ко је

\footnotetext{
* Свенка Савић (2017). Допринос изградњи мира свештеница из протестантских иркава у Војводини, Нови Сад: Удружење „Женске студије и истраживања”, Футура публикације.
} 
ко" публикацијама (у којима се до сада ниједно од ових имена није нашло), затим кроз табеларни преглед (стр. 44-46) и биограме (стр. 47-63) на основу којих могу да се прате порекло, образовање и каријере ових жена. Поред тога, део публикације представља и сепарат - мапа Војводине са обележеним местима у којима служе свештенице, уз пратеће личне фотографије и скраћене верзије биографија. На овај начин додатно се истичу и чине видљивим њихово високо образовање и ангажман унутар заједница у којима су рукоположене.

Међутим, књига представља много више од навођења биографских података свештеница о којима је реч. Поред емпиријског дела истраживања, ауторка је разговарала са некима од њих (укупно десет), а ауторизовани транскрипти разговора налазе се у другом, по обиму нешто већем, делу књиге. Читаоцима и читатељкама је на тај начин омогућено да и непосредно сазнају о животном позиву ових жена, њиховим изборима и изазовима са којима су се сусретале у обављању пастирских дужности и свештеничког позива. Свештенице одговарају на разноврсна питања, од оних везаних за приватни живот и интимна верска искуства, па све до начина на који делују протестантске заједнице у Војводини и шире.

Управо кроз њихове одговоре, неретко између редова, може да се чита изузетно комплексна историја не само превасходно религијских већ и социјалних, етничких, културалних и родних аспеката женског свештенства. Припаднице старијих генерација свештеница тако сведоче о тешкоћама теолошког образовања и верског деловања у условима материјалне оскудице и притисака тоталитарних режима; неке од њих носе ожиљке послератних прогона етничких мањина и драматичних промена демографске структуре становништа у својим локалним срединама, а које су у великој мери обележиле новију историју ових верских заједница (пре свега немачке и мађарске националне заједнице). За свештенице последње генерације изазови су другачије нарави, попут питања идентитета, или усклађивања свештеничког позива са обавезама које за њих подразумевају брак и родитељство.

Један од закључака који може да се изведе на основу документарног материјала из овог истраживања јесте да историја женског свештенства у Војводини има битно другачију тангенту од женског свештенства у истоветним или сродним заједницама у Западној Европи или Северној Америци. Док су на Западу увођењу женског свештенства претходиле деценије феминистичког активизма и, уз извесне изузетке, снажан отпор мушке хијерархије, жене унутар војвођанских протестантских цркава као и да нису биле у прилици да се боре за могућност заређења, већ да им је оно понуђено услед тешких околности и неприлика у којима су се након Другог светског рата затекле ове цркве. Једна од интервјуисаних жена речито је описала став своје црквене заједнице: „Боље да жена служи него нико” (стр. 80). Другим речима, остаје утисак да женском свештенству унутар протестантских цркава у Војводини није претходила нека нарочита еманципаторна кампања, већ је оно уведено из прагматичних разлога послератног спасавања онога што се спасити може за даљи верски живот заједнице.

Читано из феминистичке перспективе, приметно је да у наведеним транскриптима разговора преовладавају традиционалне хришћанске вредности и патријархална схватања родних улога. Уз извесно уопштавање, могло би се утврдити да је ово још један пример контраста у поређењу са 
протестантским црквама у Западној Европи и Северној Америци. Оне међу црквама које су канонски омогућиле женама да служе као свештенице по правилу припадају прогресивним, социјално либералним заједницама; као такве, дубоко су обележене либералном теологијом и савременим феминизмом, укључујући не само прихватање жена у свештеничком својству већ и, на пример, залагање за потпуно прихватање сексуалних мањина - став који верске заједнице обрађене у овом истраживању званично не деле, остајући чврсто на конзервативним становиштима својственим верској култури овог дела Европе. У том смислу, могло би се поставити интригантно питање о томе да ли жене свештенице на нашим просторима доприносе подривању или, напротив, перпетуирању традиционалних вредности и родних норми.

Сама тема доприноса жена свештеница изградњи мира, иако средишња у наслову, чини се секундарном у самом тексту - али не и периферном. О доприносу ових жена можемо читати кроз описе ьихове каритативне делатности, кроз сведочанства о пожртвованом хуманитарном раду током ратних и послератних 1990-их година, кроз сарадњу са другим верским заједницама и превазилажењем ограничења условљених конфесијом или етницитетом. Једна значајна тема која се провлачи кроз целу књигу и свакако представља један од њених кључних појмова јесте интеркултуралност. Она се нарочито истиче у другом делу књиге, где свештенице новије генерације сведоче о начинима на које доприносе култури дијалога и разумевања, и то најпре кроз властите породице, односно начином на који васпитавају своју децу, али и кроз јавни школски систем, унутар којег неке од њих делују као вероучитељице. Треба додати да за већину испитаница допринос миру и афирмативан став према интеркултуралности нису нужно нешто што је родно условљено, већ они проистичу из саме природе свештеничког позива и хришћанског послања, без обзира на то да ли је реч о мушкарцу или жени у свештеничкој улози.

Многи од података и сведочанстава у овој књизи представљају до сада незабележен или слабо познат садржај у литератури. Користи од њих имаће не само истраживачи из области религијских и мировних студија, које би са̂м наслов најпре могао да привуче, већ и они који се баве историјом и положајем мањинских заједница у Србији, као и феминистичким студијама - нарочито када је реч о женском наслеђу на простору данашње Србије, односно Војводине. Овај пионирски рад проф. Савић, с обзиром на веома различите аспекте које је обухватио, треба схватити и као позив за даља истраживања ове вишеструко важне, а предуго занемариване теме. Тиме би се додатно осветлила не само историја ових трију мањинских конфесија у Војводини већ би се и додатно скренула пажња на углавном невидљив, а врло важан рад жена унутар верских заједница. 